\title{
NEW RECORDS AND RANGE EXTENSIONS OF BIRDS FROM TIMOR, ALOR AND ROTE
}

\author{
Hidayat Ashari ${ }^{* 1}$, Dewi M. Prawiradilaga ${ }^{1}$, James A. Eaton ${ }^{2}$, \\ Suparno ${ }^{1}$ and Frank E. Rheindt ${ }^{3}$ \\ ${ }^{1}$ Zoology Division (Museum Zoologicum Bogoriense), Research Center for Biology, \\ Indonesian Institute of Sciences, Jl. Raya Jakarta-Bogor Km 46, Cibinong, Bogor 16911, Indonesia \\ ${ }^{2}$ A-3A-5, Casa Indah 1, Persiaran Surian, Petaling Jaya, Selangor, 47810, Malaysia \\ ${ }^{3}$ Department of Biological Sciences, National University of Singapore, Singapore; \\ *Corresponding author: numenius.phaeopus@gmail.com
}

Received: 18 July 2018; Accepted: 2 December 2018

\begin{abstract}
The Lesser Sundas Region continues to be widely unexplored even in such relatively wellknown animal groups as birds (Aves). We report the results of an ornithological expedition from November through December 2015 to Timor, Alor and Rote islands along with some opportunistic observations made in that area between 2006 to 2015, providing details on numerous first records of bird species outside their previously known geographic or elevational ranges observed or otherwise recorded during this expedition. Our results underscore the fragmentary nature of our knowledge of the composition of the avifauna of the Lesser Sunda Islands, and demonstrate that there continues to be a large volume of significant new records and range extensions of birds on these islands.
\end{abstract}

Keywords: Alor, new island records, range extensions, Rote, Timor

\section{INTRODUCTION}

The islands of Timor, Rote and Alor are located at the eastern end of the Lesser Sunda Islands, a chain of hundreds of deep-sea islands spanning about 1,700 km between the Sunda shelf (of the Eurasian continental plate) to the west and the Sahul shelf (of the Indo-Australian plate) to the east at approximately $7.5-11^{\circ} \mathrm{S}$ and $116-127^{\circ} \mathrm{E}$ (Fig. 1). Timor, the largest of the Lesser Sunda islands (c. $30,459 \mathrm{~km}^{2}$ ), is now almost equally partitioned between the new nation of Timor-Leste (since 2002) and Indonesian West Timor. Alor (2,800 $\left.\mathrm{km}^{2}\right)$ and Rote $\left(1,226 \mathrm{~km}^{2}\right)$ are much smaller than Timor, and all three islands have remained unconnected to one another during the glacial climatic fluctuations of the Quaternary when global sea levels periodically receded by as much as $120 \mathrm{~m}$, connecting many of the other islands in the Lesser Sunda chain through land bridges (Voris, 2000; Lambeck \& Chappell, 2001; Hall, 2002; Bintanja et al., 2005).

The numerous islands of the Lesser Sundas act as stepping stones for animals and plants, with the longest sea crossing between Timor and continental Asia being less than $\sim 50$ $\mathrm{km}$. The distance from Australia to Timor is currently at least $\sim 450 \mathrm{~km}$, but during much of the Pleistocene this distance may have been reduced to $\sim 140 \mathrm{~km}$ because much of the Sahul shelf of continental Australia became exposed land. Despite their close geographic proximity, Timor and Rote would have remained isolated by a deep-sea crossing of $\sim 4 \mathrm{~km}$ during glacial peaks, whereas the distance between Timor and Alor would have been reduced only insignificantly to $29 \mathrm{~km}$ (Voris, 2000; Lambeck \& Chappell, 2001; Hall, 2002; Bintanja et al., 2005). 
Akin to other deep-sea islands in Wallacea, Timor, Rote and Alor have classical island faunas characterized by low overall species richness and relatively high levels of endemism. The proportion of bird taxa with an Australian origin is relatively high on these three islands as compared to their western Lesser Sunda counterparts, whereas the opposite is true for their Oriental bird element (Simpson, 1977; White \& Bruce, 1986; Clode \& O’Brien, 2001). Molecular studies examining the evolutionary history of Lesser Sundaic birds are scarce, but the ancestor of the Timor-endemic Timor Meliphaga Meliphaga reticulata also gave rise to the White-lined Honeyeater $M$. albilineata from northern Australia, with a separation date around 2.8 million years ago (Norman et al., 2007).

Up to 1980, there had been 24 ornithological surveys or reports on Timor (White, 1986), beginning with brief notes by William Dampier in 1699. Major collections and surveys include those of S. Müller (1828-1829), A. R. Wallace (1856-1861), D. S. Hoedt (1863-1866), H. O. Forbes (1882), C. B. Haniel (1911) (see Hellmayr, 1914), G.H.W. Stein (1931-1932) (see Mayr, 1944), and McKean et al. (1975). These studies focused on collecting birds for taxonomic purposes, particularly to identify new resident taxa. Much of these data were summarized by White \& Bruce (1986), who listed 212 bird species for Timor. Subsequent field observations have added at least 49 species, including one resident passerine bird, but most additions have been migrant waders, seabirds and rails (Trainor, 2005b; Trainor et al., 2007).

In 1993, the first ecological field study of Timor's birds was undertaken in West Timor, with new information on the relative abundance and conservation status of species in lowland forest habitats (Noske \& Saleh, 1996). That study found that in comparison with Darwin, Australia, a high percentage of resident land bird species on Timor were restricted to tropical dry forests, but few were restricted to open forests and woodlands. Migration is not an important feature of the land bird fauna of Timor, with only small numbers of Holarctic land bird migrants (e.g. Oriental Honeybuzzard Pernis ruficollis, Chinese Sparrowhawk Tachyspiza soloensis, Oriental Cuckoo Cuculus saturatus, Barn Swallow Hirundo rustica, Pacific Swift Apus pacificus, Eastern Yellow Wagtail Motacilla tschutschensis, and Arctic Leaf Warbler Seicercus borealis) and Australian migrants (Black-faced Cuckooshrike Coracina novaehollandiae, Channel-billed Cuckoo Scythrops novaehollandiae and Chysococcyx cuckoos) visiting Timor each year (Noske, 1997; Trainor et al., 2007). The island is home to 12 single-island endemics, including one undescribed species (see species accounts), along with four species shared with Rote (Eaton et al., 2016).

Compared to Timor, the much smaller and low-lying Rote (maximum elevation of $440 \mathrm{~m}$ ) is home to four endemic species (Eaton et al., 2016; Prawiradilaga et al., 2017; Ng et al., 2018). The birds of Rote have been little studied. Ten Kate collected 14 species on Rote in 1891-1893 (see Büttikofer, 1892; Mees, 1975). Father J. A. J. Verheijen visited in March- 
April 1969 and listed 90 species, including 45 species that were collected and later deposited at the Leiden Museum, 33 species that were observed and 12 species that were reported by local informants. Verheijen collected on Dao, Doö and Nusa islands and apparently 'not the zoologically most interesting part' of Rote according to Mees (1975). G.F. Mees curated Verheijen's collection, and commented on his manuscript, which was eventually published in 1976 (Verheijen, 1976). Ron Johnstone surveyed birds over 13 days in central and southern Rote and Pulau Ndana and Batu Heliana during October 1990. Paul Jepson surveyed birds in central Rote over four days in September-October 1993. These two authors published a joint paper based on their surveys which documented the 86 species they recorded (incorrectly given as 83 species in the abstract) and included 119 bird species in a review of the island's avifauna (Johnstone \& Jepson, 1996). Johnstone \& Darnell (1997a) described a new race of Southern Boobook Ninox novaeseelandiae, which has since been elevated to species level, Rote Boobook Ninox rotiensis (Eaton et al., 2016; Gwee et al., 2017). That paper documented the status and habitat use of birds on the Tapuafu peninsula of northern Rote, with particular emphasis on threatened, restricted-range and forest birds plus waterbirds.

Alor Island (maximum elevation of $1825 \mathrm{~m}$ ) is more than twice the size of Rote and has already been categorized as an Endemic Bird Area (EBA) (Stattersfield et al., 1998). Alor is connected to its smaller neighbor Pantar Island across shallow sea that has become exposed above water during Pleistocene glaciations, but the two islands together are surrounded by deep sea that has continuously isolated them from Timor Island and the Flores chain during the low sea levels of the Pleistocene ice ages (Voris, 2000). Alor has been rarely visited by ornithologists, and consequently its avifauna has also remained poorly known. A.H. Everett visited Pantar and Alor islands in March-April 1897, collecting 64 bird species on Alor and 22 species on Pantar (Hartert, 1898). The collecting on Alor 'cannot be regarded as at all an exhaustive one' because a lack of water and food hampered the visit, causing Everett to become feverish and then injure a leg which required hospitalization on Sulawesi (Hartert, 1898). The collection was enough to determine that Alor has a 'Flores ornis' (Hartert, 1898) although a few taxa typical of Timor Island, such as Olive-headed Lorikeet Trichoglossus euteles, Timor Cuckoo-dove Macropygia magna and boobooks (genus Ninox) were collected on Alor. V. von Plessen visited Alor in July-August 1927, collecting 68 specimens of 31 bird species (Rensch, 1929). Alor is home to one undescribed single-island endemic, a Myzomela, although it has two species shared only with Pantar (Trainor et al., 2012).

A major study (1987-1993) of the avifauna of the Lesser Sundas and the islands of Maluku by the Western Australian Museum (WAM) and the Indonesian Institute of Sciences (LIPI) included a visit to Pantar and Alor in April-May 1991. This work resulted in new information on the shorebirds and seabirds of Pantar and Alor (Johnstone, 1994), the discovery and description of a new form of Sunda Bush Warbler Horornis [Cettia] vulcanius 
kolichisi (Johnstone \& Darnell, 1997b) on Alor, and a redescription of the Alor Boobook (Johnstone \& Darnell, 1997a). Substantial additional information on the land birds of Alor and Pantar, including many new island records, has remained unpublished. Recent work on Alor has included the first published record of a montane bird (Lesser Shortwing Brachypteryx leucophrys) by Holmes (1995) as well as limited ornithological observations by Mason (1991, 1993) and Holmes (1995), and a status survey of the Critically Endangered Yellow-crested Cockatoo (Setiawan et al., 2000).

The aim of this paper is to document avian island range extensions and altitudinal range extensions from our recent field work on Timor, Rote and Alor islands, including records of globally threatened and restricted-range bird species. Many of the supposed new island records mentioned in Holmes (1995) and Trainor (2005a) had actually been recorded during the WAM-LIPI expeditions, so we take the opportunity to correct the record. Some of the new records documented herein are already reflected in a new field guide to the region (Eaton et al., 2016) but are actually based on this work, and are therefore presented here as novel. Taxonomy and vernacular names follow Eaton et al. (2016).

\section{MATERIALS AND METHODS}

\section{Expedition schedule}

HA, DMP, Suparno, and FER traveled to Nusa Tenggara Timur, Indonesia, from 19 November - 10 December 2015 in order to collect birds at five different sites: (1) Alor Island (Manmas: $19^{\text {th }}-23^{\text {rd }}$ November 2015; Maukuru: $25^{\text {th }}-26^{\text {th }}$ November 2015), (2) Rote Island (South Rote: $29^{\text {th }}-30^{\text {th }}$ November 2015; East Rote: $2^{\text {nd }}-4^{\text {th }}$ December 2015) and (3) Mount (= "Gunung") Mutis-Timau on $7^{\text {th }}-10^{\text {th }}$ December 2015, the highest part of Timor Island.

In addition, opportunistic observations were made by JAE during birdwatching trips to the region. JAE spent a total of 53 field days between 2006 and 2015 in West Timor: $14^{\text {th }}-$ $18^{\text {th }}$ July $2006,14^{\text {th }}-18^{\text {th }}$ July $2008,14^{\text {th }}-18^{\text {th }}$ June $2009,7^{\text {th }}-10^{\text {th }}$ July $2009,30^{\text {th }}$ July $-4^{\text {th }}$ August $2010,15^{\text {th }}-20^{\text {th }}$ July 2011, $28^{\text {th }}$ July and $30^{\text {th }}$ July $-2^{\text {nd }}$ August $2012,21^{\text {st }}$ September and $24^{\text {th }}-26^{\text {th }}$ September 2013, $11^{\text {th }}$ September and $13^{\text {th }}-17^{\text {th }}$ September $2015,2^{\text {nd }}$ October and $4^{\text {th }}-8^{\text {th }}$ October 2015. JAE went to the same well-known Timor sites on each visit Bipolo, Camplong, a forest patch near Soe, and Mount Mutis. JAE spent a total of nine field days between 2012 and 2015 on Rote: $29^{\text {th }}-30^{\text {th }}$ July 2012, $22^{\text {nd }}-23^{\text {rd }}$ September $2013,12^{\text {th }}$ $-13^{\text {th }}$ September $2015,3^{\text {rd }}-4^{\text {th }}$ October 2015 , and $14^{\text {th }}$ October 2018 . Each trip included a visit to the Lake Oendui- Daurendaye area, north Rote. On Alor, JAE invested only four field days between 2011 and 2017: $24^{\text {th }}$ October 2011, $10^{\text {th }}$ October 2014, $7^{\text {th }}$ October 2016 and $21^{\text {st }}$ October 2017. 
Ashari et al.: New records and range extensions of birds ....

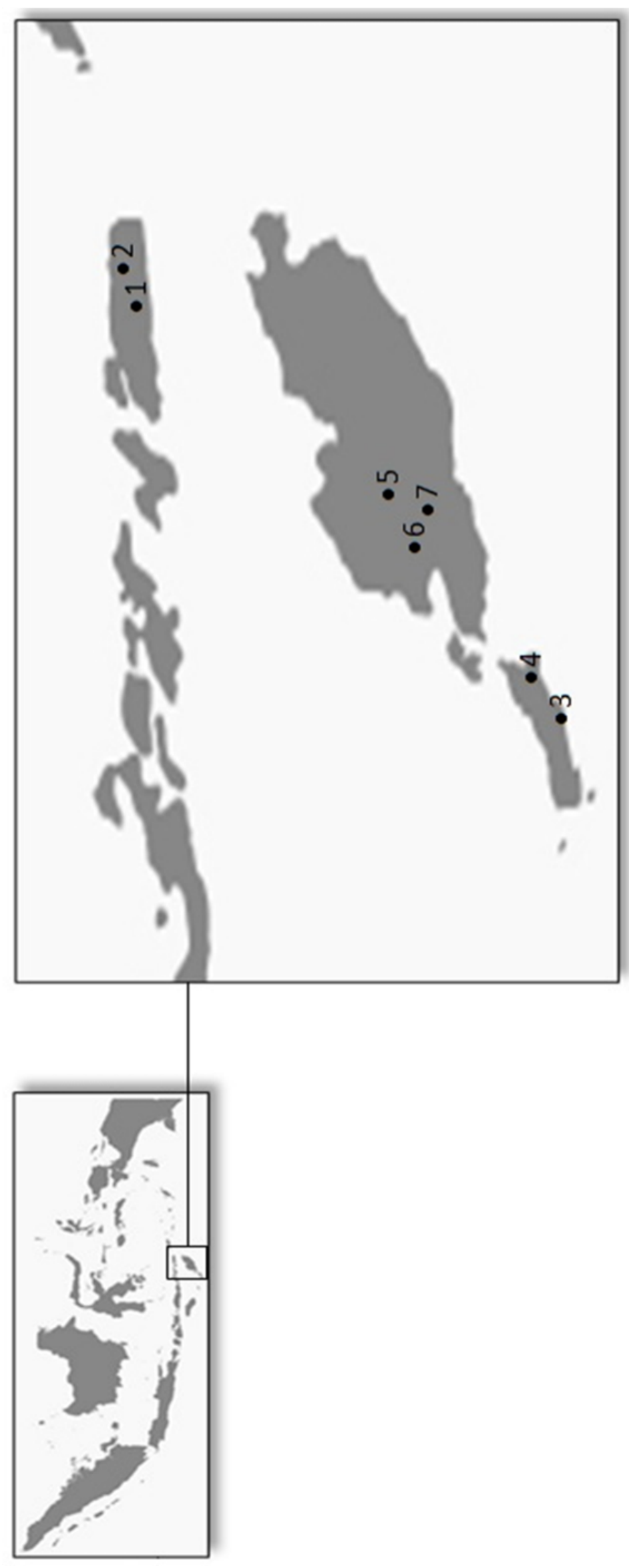

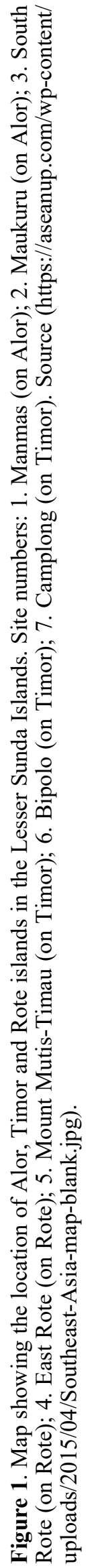


Table 1. Details on all study sites and field localities

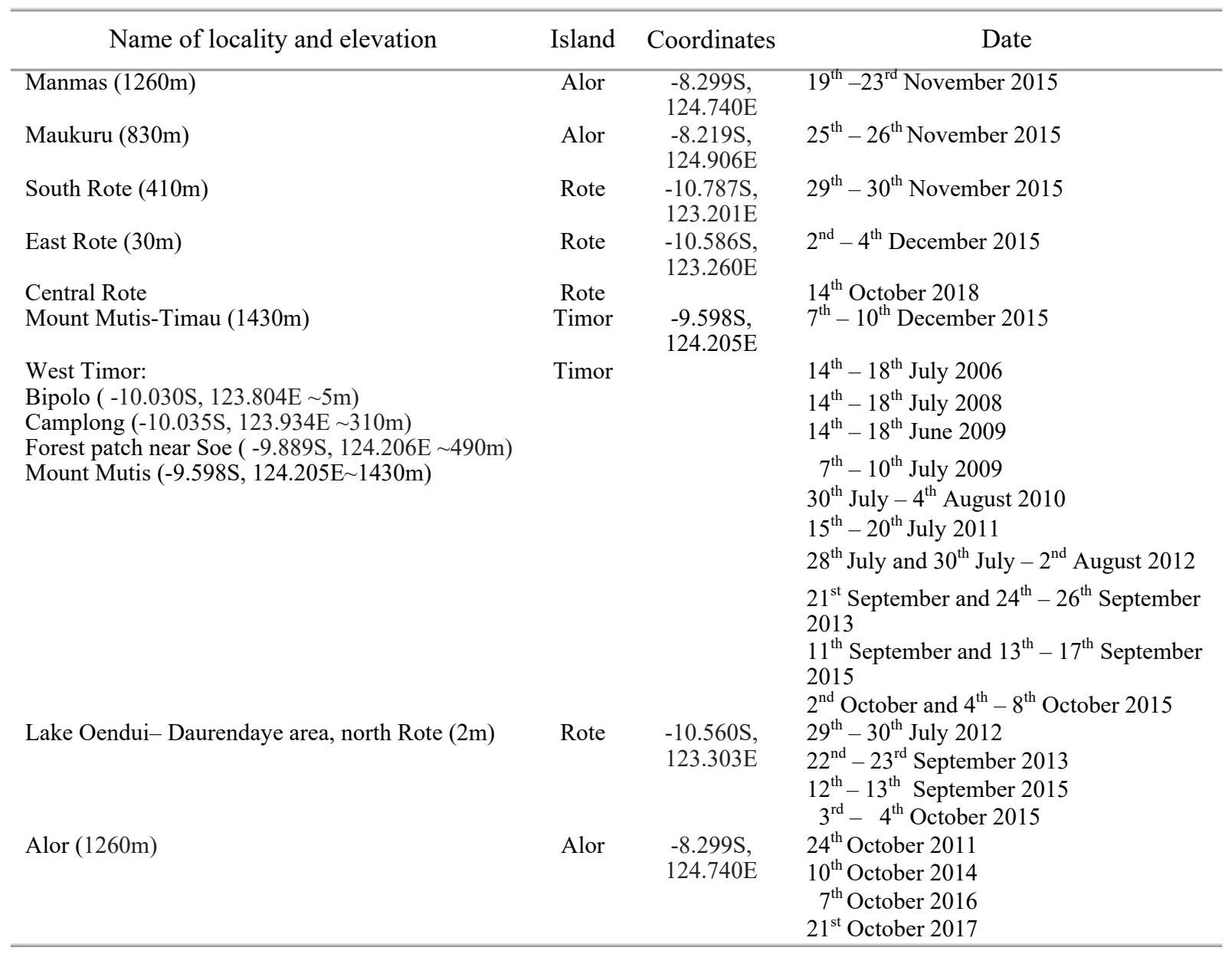

\section{Field Methods}

Birds were mist-netted with 20 ground nets of 6-12 m length, two of which were deployed as canopy nets at $\sim 7 \mathrm{~m}$ height on limited occasions in the lowlands of Maukuru, Alor. Caught individuals were subjected to the following measurements and processing steps: weight, wing length, tarsus length, bill length, tail length, total length, wing spread, presence of molt, determination of sex and age if possible, bare parts coloration. Some of the birds for which we had permits were collected, prepared as skins and deposited in Museum Zoologicum Bogoriense (MZB) for posterity, while liver and muscle tissue samples were taken for potential future DNA analysis. Only a small minority of collected birds were put into alcohol for later preparation at the MZB, while all other specimens were prepared in the field.

Birds were also observed using various brands of binoculars and sound-recorded on the occasion of regular morning and afternoon bird surveys as well as opportunistic birdwatching activities during our collecting expedition. We used an Olympus L-12 sound recorder in combination with a Sennheiser ME66 microphone for audio recordings. On JAE's field visits, birds were photographed using a Canon DSLR and Canon 300 and 400mm lenses, and more distant birds were identified using a Swarovski ATX 20-60x65m telescope. 
This contribution concentrates on new avifaunistic records, so we refrain from providing complete lists of observations or collected material and measurements.

\section{RESULTS}

We recorded 47 significant and noteworthy species of bird on all three locations. The following list showed details on numerous first records of bird species outside their previously known geographic or elevational ranges observed or otherwise recorded during this expedition. Seventeen bird species recorded from Timor, 13 from Rote, nine from Alor and eight bird species share locality between islands.

\section{DISCUSSION}

\section{Species accounts}

Grey Teal (Anas gracilis): 2 at Lake Oendui, Rote, on $13^{\text {th }}$ September 2015 seem to be the first record for the island. Also 5 at Bipolo, Timor, on $31^{\text {st }}$ July 2010.

Javan Pond Heron (Ardeola speciosa): 1 in non-breeding plumage in a little stream in East Alor near Maukuru on $25^{\text {th }}$ November 2015 appears to be the first record for Alor.

Australian Darter (Anhinga novaehollandiae): 2 on Lake Oendui, Rote, on $12^{\text {th }}-13^{\text {th }}$ September and $3^{\text {rd }}-4^{\text {th }}$ October 2015 , followed by 4 individuals on $1^{\text {st }}$ December 2015 at the same locality, possibly the first island records.

Black Bittern (Dupetor flavicollis): 1 flushed from a dry paddy by FER on $30^{\text {th }}$ November 2015 in South Rote at early dusk is a confirmation of this species' presence on Rote, following Verheijen's (1976) uncertain record.

Oriental Honeybuzzard (Pernis ruficollis): Commonly encountered throughout the study period on all three islands. Past literature has suggested the possibility of a resident population in the Lesser Sundas due to the species being recorded year-round (Coates \& Bishop, 1997). However, all birds photographed or studied in our work have proven to be immatures of the race orientalis, suggesting non-breeding birds over-summering in the region. However, we recommend detailed documentation of future sightings to confirm this finding.

Flores Hawk Eagle (Nisaetus floris) CR: A pair was seen perched and vocalizing above Apui-Manmas on $10^{\text {th }}$ October 2014 at $1050 \mathrm{~m}$ (JAE). Possibly the same pair was observed again by FER on $20^{\text {th }}-23^{\text {rd }}$ November 2015 at the same locality, including the performance of aerial displays, and at least another individual was seen there in flight (possibly more). On $25^{\text {th }}$ November 2015, at least 1 was seen flying over in East Alor near Maukuru, where FER later also distantly heard one at least once. On $7^{\text {th }}$ October 2016, JAE recorded presumably the same displaying pair above Apui-Manmas, at $1100 \mathrm{~m}$, followed by singles 
Table 2. Bird list, study site and data retrieval

\begin{tabular}{|c|c|c|c|c|c|}
\hline \multirow{2}{*}{ Species } & \multicolumn{3}{|c|}{ Location } & \multirow{2}{*}{$\begin{array}{c}\text { Observa- } \\
\text { tion }\end{array}$} & \multirow{2}{*}{$\begin{array}{c}\text { Mist- } \\
\text { netting }\end{array}$} \\
\hline & Timor & Rote & Alor & & \\
\hline Grey Teal (Anas gracilis) & + & & & + & \\
\hline Javan Pond Heron (Ardeola speciosa) & & & + & + & \\
\hline Australian Darter (Anhinga novaehollandiae) & & + & & + & \\
\hline Black Bittern (Dupetor flavicollis) & & + & & + & \\
\hline Oriental Honeybuzzard (Pernis ruficollis) & + & + & + & + & \\
\hline Flores Hawk Eagle (Nisaetus floris) & & & + & + & \\
\hline Chinese Sparrowhawk (Accipiter soloensis) & + & & & + & \\
\hline Green Pygmy-goose (Nettapus pulchellus) & + & & & + & \\
\hline Ruddy-breasted Crake (Porzana fusca) & + & & & + & \\
\hline Spotless Crake (Porzana tabuensis) & + & & & + & \\
\hline Common Moorhen (Gallinula chloropus) & + & & & + & \\
\hline Greater Painted-snipe (Rostratula benghalensis) & + & & & + & \\
\hline Asian Dowitcher (Limnodromus semipalmatus) & + & & & + & \\
\hline Metallic Pigeon (Columba vitiensis metallica) & & & + & + & \\
\hline Eucalypt Cuckoo-dove (Macropygia sp. A) & + & & + & + & \\
\hline Australian Brush Cuckoo (Cacomantis variolosus whitei) & & + & & + & \\
\hline Little Bronze Cuckoo (Chrysococcyx minutillus jungei) & & & + & + & \\
\hline Rote Boobook (Ninox rotiensis) & & + & & + & \\
\hline Timor Nightjar (Caprimulgus sp. B) & + & + & & + & \\
\hline Mees's Nightjar (Caprimulgus meesi) & & & + & + & \\
\hline White-throated Needletail (Hirundapus caudacutus) & & + & + & + & \\
\hline Pacific Swift (Apus pacificus) & & + & & + & \\
\hline House Swift (Apus nipalensis) & & + & & + & \\
\hline Yellow-crested Cockatoo (Cacatua sulphurea occidentalis) & + & & + & + & \\
\hline Marigold Lorikeet (Trichoglossus capistratus) & + & & & + & \\
\hline Timor Bushchat (Saxicola gutturalis) & & + & & + & + \\
\hline Sunda Thrush (Zoothera andromedae) & & & + & + & \\
\hline Orange-banded Thrush (Geokichla peronii) & + & & & + & \\
\hline Island Thrush (Turdus poliocephalus schlegelii) & + & & & + & \\
\hline Timor Thicketbird (Buettikoferella bivittata) & + & & & + & \\
\hline Timor Stubtail (Urosphena subulata) & & + & + & + & + \\
\hline Rote Leaf Warbler (Phylloscopus rotiensis) & & + & & + & + \\
\hline Ashy-bellied White-eye (Zosterops citrinellus citrinellus) & + & + & + & + & + \\
\hline Mountain White-eye (Zosterops montanus montanus) & & & + & + & + \\
\hline Timor Heleia (Heleia muelleri) & + & & & + & \\
\hline Snowy-browed Flycatcher (Ficedula hyperythra clarae) & + & & & + & + \\
\hline Little Pied Flycatcher (Ficedula westermanni) & & + & & + & \\
\hline Black-banded Flycatcher (Ficedula timorensis) & + & & & & + \\
\hline Wallacean Spectacled Monarch (Symposiachrus trivirgatus) & & + & & + & + \\
\hline Fawn-breasted Whistler (Pachycephala orpheus) & + & + & & + & + \\
\hline Black-faced Cuckooshrike (Coracina novaehollandiae) & & + & & + & \\
\hline Javan Myna (Acridotheres javanicus) & + & & & + & \\
\hline Common Hill Myna (Gracula religiosa venerata) & & & + & + & \\
\hline Rote Myzomela (Myzomela irianawidodoae) & & + & & + & + \\
\hline Alor Myzomela (Myzomela sp. C) & & & + & + & + \\
\hline Tricoloured Parrotfinch (Erythrura tricolor) & & + & & + & \\
\hline Mount Mutis Parrotfinch (Erythrura sp. D) & + & & & + & \\
\hline
\end{tabular}


perched by the roadside at $850 \mathrm{~m}$ and $600 \mathrm{~m}$ later the same day, presumably referring to different individuals. These records constitute a further confirmation of this Critically Endangered bird species on Alor following Collaerts et al. (2013).

Chinese Sparrowhawk (Accipiter soloensis): Two confirmed sightings on Timor, identified by FER, include 1 adult female at Bipolo $\left(15^{\text {th }}\right.$ November 2015) seen perched after dawn, and then seen in flight and tape-recorded as she uttered an alarm series; and 1 adult in the Kupang Area ( $9^{\text {th }}$ December 2015) briefly seen flying by and identified based on its extensive black underwing tips, with possible additional sightings in the Kupang Area. The species is known from Timor as a winter visitor, but our sightings add to an understanding that this species may not be as rare on Timor in the northern winter as previously assumed.

Green Pygmy-goose (Nettapus pulchellus): A pair at Bipolo both on $15^{\text {th }}$ November and $10^{\text {th }}$ December 2015 (seen by FER) are new records for West Timor. The species was first recorded in Timor Leste in 2004 (Trainor, 2005b), and is a presumed breeding resident there (Trainor, 2011).

Ruddy-breasted Crake (Porzana fusca): A singleton at Bipolo, Timor, on $15^{\text {th }}$ November 2015 (seen by FER), showing well in response to playback, is the first record for West Timor, following the first records for the island on Timor Leste, where birds were recorded at three localities in 2004 (Trainor, 2005b).

Spotless Crake (Porzana tabuensis): A singleton at Bipolo, Timor, on $10^{\text {th }}$ December 2015 (seen by FER) was the first record for West Timor, following previous records from Timor Leste in 2004 (Trainor, 2005b).

Common Moorhen (Gallinula chloropus): At least three individuals were seen by FER at Bipolo, Timor, on $15^{\text {th }}$ November 2015 and four on $10^{\text {th }}$ December 2015, the latter four swimming out in the open in the middle of a pond. Clear white flank stripes, brown backs and dark greenish legs confirm the identification as this species, representing a new record for Timor.

Greater Painted-snipe (Rostratula benghalensis): A female at Bipolo, Timor, on $8^{\text {th }}$ October 2015 (JAE) and $15^{\text {th }}$ November 2015 (FER) was a new record for Timor. The deep red body coloration confirmed the identification, ruling out the chance of a vagrant Australian Painted -snipe Rostratula australis.

Asian Dowitcher (Limnodromus semipalmatus): A single at Bipolo, Timor, on $10^{\text {th }}$ December 2015 (FER) closely associated with five Black-tailed Godwits Limosa limosa and was the first record for West Timor, following two records in 2005 from Timor Leste (Trainor, 2005b).

Metallic Pigeon (Columba vitiensis metallica): Two near Maukuru in East Alor on $25^{\text {th }}$ November 2015 (FER) observed feeding in a fruiting tree appear to be the first record for Alor. 
Eucalypt Cuckoo-dove (Macropygia sp. A): On $17^{\text {th }}$ July 2009, JAE sound-recorded an unknown pigeon vocalization on Mount Mutis, Timor. Locating the source of the sound, he was surprised to see it originated from a 'Little Cuckoo-dove' $M$. ruficeps, a species he is well familiar with and which sounds distinctly different. Subsequently, JAE made sound recordings matching this distinct vocalization on Sumba, while Filip Verbelen (in litt.) also sound-recorded a similar vocalization on Alor. The supposed race of Little Cuckoo-dove $M$. ruficeps on Timor, Alor and Sumba is orientalis, whose type locality is Sumbawa. However, vocalizations from Flores and Sumbawa are similar to the birds from mainland Southeast Asia and the Greater Sundas (unpublished data), and point to the birds from Timor, Sumba and Alor being an undescribed taxon. The plumage of this novel form appears to be significantly more reddish in overall appearance than orientalis from elsewhere in the Lesser Sundas, with a less distinct pale belly and throat. Records from Timor are predominantly from Eucalypt forest on the slopes of Mount Mutis between 1300-1900 m, with records as low as $600 \mathrm{~m}$ near Soe. On Sumba, birds have been recorded between 300-700 m, and above $600 \mathrm{~m}$ on Alor. FER recorded a total of $\sim 40$ on Alor around both Apui-Manmas and East Alor in November and December 2015. Further work is needed to confirm the taxonomic identity of these populations, which we here flag as an undescribed species to science.

Australian Brush Cuckoo (Cacomantis variolosus whitei): In dry areas around South Rote, $\sim 5-6$ singletons of a very pale coloration typical for this subspecies were noted on $29^{\text {th }}-30^{\text {th }}$ November 2015. These constitute a first record for Rote. The occurrence of this taxon here is unsurprising as it is regularly noted on Timor.

Little Bronze Cuckoo (Chrysococcyx minutillus jungei): A juvenile with solid-pale underparts, lack of an eye ring, the presence of a slight pale supercilium and uniform olivebrown upperparts was observed being fed by a Gerygone in white eucalypt savannah in East Alor on $26^{\text {th }}$ November 2015, indicating that it must stem from a resident population, here presumably attributable to subspecies jungei. The fast trill of this species was also heard a few kilometers from this site on Alor, corroborating the occurrence of this species on this island.

Rote Boobook (Ninox rotiensis): We commonly found the species by voice in the small remaining tall forest patch in South Rote $\left(28^{\text {th }}-30^{\text {th }}\right.$ November 2015), although sightings in this habitat are very difficult because they prefer the higher stratum. We also had visual encounters of singletons or pairs near Lake Oendui in East Rote on $29^{\text {th }}$ July 2012, $22^{\text {nd }}$ September 2013, $12^{\text {th }}$ September 2015, $2^{\text {nd }}$ October 2015 and $2^{\text {nd }}$ December 2015.

Timor Nightjar (Caprimulgus sp. B): Nightjar populations on Timor and Rote previously attributed to Large-tailed Nightjar C. macrurus are indeed visually and behaviorally similar, but exhibit unique vocalizations. More work needs to be carried out, but we here attribute 
these populations to an undescribed species. We have observed and recorded these undescribed nightjars regularly on each visit from 2010-2015 in a forest patch near Soe, with up to four individuals encountered. On $14^{\text {th }}$ October 2018 , one was discovered singing by Mike Nelson after dusk at $1900 \mathrm{~m}$ asl in central Rote, the first confirmed record for the island. Sound recordings and photographs were taken, confirming the presence of this undescribed taxon on Rote.

Mees's Nightjar (Caprimulgus meesi): Seen well in Manmas village on Alor on $20^{\text {th }}-21^{\text {st }}$ November 2015, where the species is common vocally in savannah and several individuals were flushed from the road in twilight; also commonly heard near Maukuru in East Alor. These records corroborate the occurrence of this species on Alor, where it had previously been encountered by Filip Verbelen (Trainor et al., 2012).

White-throated Needletail (Hirundapus caudacutus): The sighting of $~ 10$ in Apui-Manmas, Alor, and a total of $\sim 20$ throughout Rote in late November and early December 2015 possibly refer to new island records.

Pacific Swift (Apus pacificus): A single on Rote on $3^{\text {rd }}$ December 2015 appears to be a new, albeit unsurprising, island record.

House Swift (Apus nipalensis): A sighting of $\sim 5$ in South Rote on $1^{\text {st }}$ December 2015 may be a new record for the island.

Yellow-crested Cockatoo (Cacatua sulphurea occidentalis) CR: Presumably the same single individual at Bipolo, Timor, on each visit between 2009 and 2013 may have been either an escaped bird or a wandering, remnant individual from the now-extinct population in West Timor. On Alor, an exceptional flock of 17 was encountered in the late afternoon of $7^{\text {th }}$ October 2014 in a deep gulley well away from habitation, with at least eight noted in the same area on $7^{\text {th }}$ October 2017,10 on $12^{\text {th }}$ October 2017 and $13^{\text {th }}$ on $21^{\text {st }}$ October 2017 . The latter records are an important confirmation of the persistence of this quickly disappearing species on Alor.

Marigold Lorikeet (Trichoglossus capistratus): The only record of this once-common Timor resident during our work period was of six individuals on $31^{\text {st }}$ July 2010 in dry woodland approximately $10 \mathrm{~km}$ north of Bipolo on Timor. The dearth of field observations of this species in recent years points to its rapid extermination from West Timor as a consequence of poaching for the trade.

Timor Bushchat (Saxicola gutturalis): During each of our visits to Rote, we noted that the unnamed local island population appears to have consistently distinct vocalizations from those on Timor. Rote males lack any white on the tail, contrasting with the distinctly white upper halves of the outer tail feathers in the nominate race gutturalis from Timor. These morphological and vocal traits would suggest deep differentiation of the Rote population. However, little modern field information exists about the geographically intermediate 
population on Semau Island, which is attributed to its own subspecies luctuosus. Semau males are described as having "less white on the tail and wings than nominate" (Eaton et al., 2016), but nothing is known about their vocalizations. Rote birds may therefore sit at the final terminus of a westward cline of decreasing amounts of white in the tail, or they may exhibit discrete, non-clinal variation in this trait. It is obvious that more research is required to lift the mystery of the taxonomic status of the Rote population. In our fieldwork, DNA material of Rote birds was collected, which will hopefully facilitate such future analyses once Semau birds have been studied.

Sunda Thrush (Zoothera andromedae): A single bird was seen well in a lush, steep gully at $1200 \mathrm{~m}$, below the town of Manmas, Alor, on $23^{\text {rd }}$ November 2015 (FER), constituting a new record for Alor.

Orange-banded Thrush (Geokichla peronii): Between 2009-2015, at least two pairs were regularly encountered at $1850 \mathrm{~m}$ on most of our visits to Mount Mutis, Timor, and even seen in the same view as Chestnut-backed Thrush G. dohertyi, constituting a new upper elevational record.

Island Thrush (Turdus poliocephalus schlegelii): On all our visits to Mount Mutis, Timor, we commonly encountered this species down to $1350 \mathrm{~m}$, which is an elevational range extension of this taxon.

Timor Thicketbird (Buettikoferella bivittata): On $7^{\text {th }}$ December 2015, the distinct vocalizations of this species were heard on Mount Mutis, Timor, at $\sim 1550 \mathrm{~m}$. This elevation constitutes an extension to the previous altitudinal occurrence known for this species (Coates \& Bishop, 1997), possibly indicating upward shifts in elevation in response to climate change.

Timor Stubtail (Urosphena subulata): On all our visits to Rote, we encountered, studied, sound-recorded and - during one visit - collected individuals of an undescribed taxon of this species complex. This taxon was encountered commonly in both South Rote and East Rote. We also encountered, studied, recorded and collected the undescribed population of stubtail on Alor that has previously been documented by Trainor (2005c) and Trainor et al. (2012). Additional research into these forms is required and must be published separately.

Rote Leaf Warbler (Phylloscopus rotiensis): On Rote, we studied individuals belonging to a distinct undescribed species of leaf-warbler. The results of these studies are presented elsewhere ( $\mathrm{Ng}$ et al., 2018).

Ashy-bellied White-eye (Zosterops citrinellus citrinellus): We commonly encountered this species on all three islands. However, on $7^{\text {th }}$ December 2015 , we saw $\sim 5$ and mist-netted $\sim 8$ individuals at $\sim 1550 \mathrm{~m}$ on Mount Mutis, Timor, that were visibly different in coloration and voice from the extremely yellow-crowned, pale-eyed Z. montanus that is to be expected here. This record constitutes an elevational range extension of the species on Timor, indicating possible upward altitudinal displacement in response to climate change. 
Mountain White-eye (Zosterops montanus montanus): The species has previously been recorded from Alor by Trainor et al. (2012) on the basis of observations of a thriving population in the highlands of Alor near the village of Manmas. During our time at Manmas $\left(20^{\text {th }}-24^{\text {th }}\right.$ November 2015), we noted an abundance of Zosterops white-eyes around the village and observed, studied and collected them. However, our vocal and plumage comparisons with specimens of Ashy-bellied White-eye Z. citrinellus collected on Rote and Timor revealed very limited differentiation. We subsequently sequenced mitochondrial (mtDNA) barcodes of 5 of our individuals and compared them with Genbank barcodes, confirming that the white-eyes from Manmas, Alor, are scarcely distinguishable from other Ashy-bellied White-eyes on mtDNA but very different from Mountain White-eyes Z. montanus. While at Manmas, we did not observe any pronounced variability within the white -eye population of the area, ruling out the presence of two sympatric species. Hence, we attribute previous records of Mountain White-eye on Alor to misidentifications and confirm the occurrence of Ashy-bellied White-eye on Alor up to $>1100 \mathrm{~m}$.

Timor Heleia (Heleia muelleri): On all our visits to Mount Mutis, Timor, between 2009 and 2015 , we recorded this species up to $1850 \mathrm{~m}$. These records constitute an elevational range extension of this species, possibly in response to a warming climate.

Snowy-browed Flycatcher (Ficedula hyperythra clarae): Commonly encountered (and also mist-netted) on our visits to Mount Mutis, Timor, usually from $1550-1750 \mathrm{~m}$. JAE had a record at $1850 \mathrm{~m}$, constituting an elevational range extension of this species on Timor.

Little Pied Flycatcher (Ficedula westermanni): Visual encounters of a total of $\sim 5$ seen in the tall remaining forest patch at $\sim 400 \mathrm{~m}$ elevation in South Rote $\left(28^{\text {th }}-30^{\text {th }}\right.$ November 2015) constitute a new island record for Rote. We also obtained a sound recording from one of these birds.

Black-banded Flycatcher (Ficedula timorensis): On $8^{\text {th }}$ December 2015, 1 male was collected at $\sim 1550 \mathrm{~m}$ on Mount Mutis, Timor, a considerable elevational range extension of this species.

Wallacean Spectacled Monarch (Symposiachrus trivirgatus): From $28^{\text {th }}-30^{\text {th }}$ November 2015, we encountered $\sim 12$ in a tall forest patch in South Rote, and sound-recorded and collected two of them. This record constitutes a new island record for Rote.

Fawn-breasted Whistler (Pachycephala orpheus): We here outline a pattern of character displacement between P. orpheus and P. calliope on Timor and Rote that has likely not been documented before. On Timor, the two species can occur together, but $P$. orpheus prefers the lowlands, while $P$. calliope is much more common at montane elevations. Nevertheless, on all our visits to Mount Mutis, Timor, we encountered them side-by-side at elevations up to $1850 \mathrm{~m}$, which constitutes an elevational range extension for P. orpheus on Timor. Visual identification of these two species on Timor is challenging based on coloration: pale edging on the wings in orpheus may create a pale wingbar effect that is not shown in such a 
pronounced manner in calliope. However, the two display massive differences in dimensions, with a large and heavy calliope not overlapping in measurements with orpheus, and the strongly repetitive whiplash song of orpheus is easily told from the less distinct song of calliope. On Rote, where calliope is absent, orpheus exhibits much larger overall measurements than the population on Timor, suggesting that the absence of calliope allows it to expand into ecological niches that require a larger size. The adult male orpheus has an overall total length of $16.5-17 \mathrm{~cm}$ and body weight of 21 grams, larger than the female which is $15.0-16.1 \mathrm{~cm}$ in total length and has a body weight of $19-20$ grams.

Black-faced Cuckooshrike (Coracina novaehollandiae): Three birds near Lake Oendui on $3^{\text {rd }}$ October 2015 constitute a new island record for Rote.

Javan Myna (Acridotheres javanicus): On all our visits to coastal West Timor, we have found this introduced species commonly, with regular records of more than a dozen individuals around Kupang and Bipolo. These records illustrate the rapid spread of this invasive species through the Lesser Sundas.

Common Hill Myna (Gracula religiosa venerata): Relatively few encounters on Alor were recorded during our study period: one was seen near Manmas on $24^{\text {th }}$ October 2011, and then $\sim 5$ below Apui, a pair below Manmas, and $\sim 4$ near Maukuru in East Alor between $20^{\text {th }}-25^{\text {th }}$ November 2015. The main vocalization of this taxon, a harsh ascending hiss, is very different from other races. The taxon venerata occurs from Sumbawa to Alor, is vocally and morphometrically distinct from other races, could be elevated to full species level in the future (Eaton et al., 2016), and has already been elevated to species status by some authorities (del Hoyo et al., 2016). With very few recent records from elsewhere in its range, Alor is a stronghold for the taxon (Eaton et al., 2015). In 1991 it was described as 'moderately common', and as 'locally common' in 2002. Our sparse records, along with few records also from Pantar (Trainor et al., 2012), underscore the sorry conservation plight of this taxon.

Rote Myzomela (Myzomela irianawidodoae): This species was newly described by our team in a recent contribution published elsewhere (Prawiradilaga et al., 2017) on the basis of this fieldwork.

Alor Myzomela (Myzomela sp. C): An undescribed taxon from Alor, this form was found to be uncommon in high-elevation savannah at Manmas (Alor) around $\sim 1300 \mathrm{~m}$. Only three males were seen well between $20^{\text {th }}-23^{\text {rd }}$ November 2015 , with one more male collected here. Previously, on $7^{\text {th }}$ October 2014, an adult male and presumed immature were seen at $1300 \mathrm{~m}$ at Manmas, with four recorded on $7^{\text {th }}$ October 2016. The description of this new species will be published elsewhere (Irham et al., in prep.)

Tricoloured Parrotfinch (Erythrura tricolor): On $29^{\text {th }}$ November 2015, FER observed 2 adults at the edge of a tall forest patch and in open scrub, respectively, in South Rote. These records constitute a new island record for Rote. 
Mount Mutis Parrotfinch (Erythrura sp. D): On $1^{\text {st }}$ August 2012, JAE discovered two male parrotfinches Erythrura at $1850 \mathrm{~m}$ on Mount Mutis, Timor. The birds were instantly recognizable as a potentially new taxon, and a series of photographs were taken. Later the same day, another six birds were located, one showing the same striking plumage as the earlier sighting, and five other birds, two presumed females, and three presumed immatures. Subsequently, this undescribed taxon has been observed by JAE in the same area, and down to $1400 \mathrm{~m}$ in September 2013, September 2015 and October 2015, with a maximum count of 20, associating with Tricoloured Parrotfinches in September 2013. This montane bird is presumably a Timor replacement of the superficially similar, more widespread Blue-faced Parrotfinch E. trichroa that is found on Sulawesi, Moluccas and New Guinea. Erythrura parrotfinches had already been seen on prior visits to Mount Mutis in July 2008, July 2009 and August 2010, but all of these were immatures and/or females, lacking any grey tones on the underparts, and were therefore not instantly identifiable as the new taxon.

Description: The presumed adult male has extensive bright-red ear coverts extending down to the sides of the throat; a blue forecrown and lores, extending down to the throat, slightly darker around the lores; a wholly emerald-green body with a bright-red rump and uppertail, and pointed central tail feathers extending slightly beyond rest of tail; a black bill with a bulging upper mandible appearing slightly more bulbous than Tricoloured Parrotfinch; pink legs. The appearance of the bird resembles that of Red-eared Parrotfinch E. coloria, endemic to Mindanao, Philippines (over $2000 \mathrm{~km}$ to the north), the most recent Erythrura species to be described to science in 1961 (Ripley \& Rabor, 1961). However, the Red-eared Parrotfinch shows more extensive blue on the face, extending just behind the eye, restricting the amount of red on the ear coverts, and has a green throat.

Presumed adult female: Hint of red on earcoverts and blue tinge in loral area. Emerald-green body with red rump and uppertail. Black bill; pink legs.

Presumed immature: Dull emerald-green crown and upperparts; bright-red rump and uppertail; face and underparts much paler green with a hint of buff. Black bill; pink legs. This plumage differs from immature Tricoloured Parrotfinch as it lacks any grey tones to the underparts.

Much time was invested on Mount Mutis, Timor, in early December 2015 to capture this new species to science, but we did not succeed in the end, and extensive effort in the field resulted in only a single sighting of a male at $\sim 1550 \mathrm{~m}$ in disturbed forest. Based on comments by locals, who know this species well, and based on its seeming absence at sites where it is otherwise reliable, we infer that this species moves downslope and into rice paddies in the rainy months (especially December) and would have largely deserted its usual breeding sites. More field efforts are needed in the future to collect material that will allow a scientific description of this distinct new species. 


\section{ACKNOWLEDGMENTS}

The Ministry of Research, Technology\& Higher Education of Indonesia issued a research permit number 9/TKPIPA/E5/Dit.KI/IX/2015 dated $9^{\text {th }}$ September 2015 to FER. The Research Centre for Biology-LIPI was the official sponsor of the research. FER acknowledges funding by a Singapore Ministry of Education grant (WBS R-154-000-658-112). We thank the East Nusa Tenggara Forestry Office (BKSDA Nusa Tenggara Timur) for issuing transport permits of the bird specimens to the Museum Zoologicum Bogoriense - LIPI. On Rote, we thank Pak Sami for help with transport. In Rote Selatan, Pak Mesak was our reliable field assistant. Pak Rens Maku from Bolatena village is acknowledged for having assisted various co-authors with fieldwork on Rote Timur during multiple visits. On Alor, we thank Pak Ba'i for assistance with transport. We are indebted to Pak Simeon and Pak Yanto for their field assistance and accommodation around Manmas, Alor. In East Alor, around the area of Padang Panjang, we benefitted from the kind field assistance and accommodation provided by Pak Benser and Pak Tis. On Timor, Pak Ona was our pleasant driver, and Pak Mateus provided accommodation in the village of Fatumnasi on the slopes of Mount Mutis. We thank to Mike Nelson for providing data from Central Rote, Keren R. Sadanandan and Nathaniel Ng for various types of assistance.

\section{REFERENCES}

Bintanja, R., van de Wal, R.S. \& Oerlemans, J. 2005. Modelled atmospheric temperatures and global sea levels over the past million years. Nature, 437: 125-128.

Büttikofer, J. 1892. On a collection of birds from the islands of Flores, Sumba and Rotti. Notes Leyden Museum, 14: 193-207.

Clode, D. \& O'Brien, R. 2001. Why Wallace drew the line: a re-analysis of Wallace's bird collections in the Malay Archipelago and the origins of biogeography. In I. Metcalfe, J.M.B. Smith, M. Morwood \& I. Davidson, eds. Faunal and Floral Migrations and Evolution in SE AsiaAustralasia. Lisse: A.A. Balkema Publishers: 113-121.

Collaerts, P., Collaerts, E., Verbelen, P. \& Trainor, C.R. 2013. Discovery of the critically endangered Flores Hawk Eagle Nisaetus floris on Alor island, Indonesia. Birding ASIA, 19: 48-51.

Coates, B.J. \& Bishop, K.D. 1997. A guide to the birds of Wallacea: Sulawesi, the Moluccas and Lesser Sundas, Indonesia. Alderley: Dove Publications.

del Hoyo, J., Collar, N.J., Christie, D.A., Elliot, A., Fishpool, L.D.C., Boesman, P. \& Kirwan, G.M. 2016. HBW and Birdlife International Illustrated Checklist of the Birds of the World. Volume 2: Passerines. Barcelona: Lynx Edicions and Birdlife International.

Eaton, J.A., Shepherd, C.R., Rheindt, F.E., Harris, J.B.C., van Balen, S., Wilcove, D.S. \& Collar, N.J. 2015. Trade-driven extinctions and near-extinctions of avian taxa. Forktail, 31: 1-12.

Eaton, J.A., Brickle, N.W., van Balen, S. \& Rheindt, F.E. 2016. Birds of the Indonesian Archipelago: Greater Sundas and Wallacea. $1^{\text {st }}$ ed. Barcelona: Lynx Edicions.

Gwee, C. Y., Christidis, L., Eaton, J. A., Norman, J. A., Trainor, C. R., Verbelen, P., \& Rheindt, F. E. 2017. Bioacoustic and multi-locus DNA data of Ninox owls support high incidence of extinction and recolonisation on small, low-lying islands across Wallacea. Molecular Phylogenetics and Evolution, 109: 246-258.

Hall, R. 2002. Cenozoic geological and plate tectonic evolution of SE Asia and the SW Pacific: computer-based reconstructions and animations. Journal of Asian Earth Sciences, 20(4): 353-434. 
Hartert, E. 1898. On the birds of Lomblen, Pantar and Alor. Novitates Zoologicae, 5: 455-476.

Hellmayr, C.E. 1914. Die Avifauna von Timor. In C.B. Haniel, ed. Zoologie von Timor. Ergebnisse der unter Leitung von Joh. Wanner im Jahre 1911 ausgeführten Timor-Expedition. Stuttgart: Im Kommissionsverlag der E. Schweizerbartschen Verlags Buchhandlung: vol. 1(1): 1-112, pl. 1, figs 1-3.

Holmes, D.A. 1995. Additions to the avifauna of Pulau Alor, Nusatenggara. Kukila, 7: 155-156.

Johnstone, R.E. \& Jepson, P. 1996. The birds of Roti island, Nusa Tenggara, Indonesia. Western Australian Naturalists, 21(1): 23-36.

Johnstone, R.E. \& Darnell, J.C. 1997a. Description of a new subspecies of Boobook Owl Ninox novaeseelandiae (Gmelin) from Roti Island, Indonesian. Western Australian Naturalis, 21(3): $161-173$.

Johnstone, R.E. \& Darnell, J.C. 1997b. Description of a new subspecies of bush-warbler of the genus Cettia from Alor Island, Indonesia. Western Australian Naturalis, 21(3):145-151.

Johnstone, R.E. \& Jepson, P. 1996. The birds of Roti island, Nusa Tenggara, Indonesia. Western Australian Naturalists, 21(1): 23-36.

Lambeck, K. \& Chappell, J. 2001. Sea level change through the last glacial cycle. Science, 292(5517): 679-686.

Mason, V. 1991. A journey to the spice islands. Tjerutjuk, 1: 4-8.

Mason, V. 1993. A journey to the spice islands. Tjerutjuk, 2: 2.

Mayr, E. 1944. The birds of Timor and Sumba. Bulletin American Museum Natural History, 83: $123-194$.

McKean, J.L., Mason, I.J. \& O'Connor L.W. 1975. Birds not previously recorded from Timor. Emu, 75: 62-64.

Mees, G.F. 1975. A list of the birds known from Roti and adjacent islets (Lesser Sunda Islands). Zoologische Mededelingen, 49: 115-140.

Ng, N.S.R., Prawiradilaga D.M., Ng, E.Y.X., Suparno, Ashari, H., Trainor, C., Verbelen, P. \& Rheindt, F.E. 2018. A striking new species of leaf warbler from the Lesser Sundas as uncovered through morphology and genomics. Scientific Reports, 8:15646. DOI:10.1038/s41598-01834101-7.

Norman, J.A., Rheindt, F.E., Rowe, D.L. \& Christidis, L. 2007. Speciation dynamics in the AustraloPapuan Meliphaga honeyeaters. Molecular Phylogenetics and Evolution, 42: 80-91.

Noske, R.A. \& Saleh, N. 1996. The conservation status of forest birds in West Timor. In Kitchener, D. \& Suyanto, A., eds. Proceeding First International Conference on Eastern IndonesianAustralian Vertebrate Fauna. Manado, Indonesia. Jakarta: Indonesian Institute of Sciences (LIPI) and Western Australian Museum: pp. 65-74

Noske, R.A. 1997. The ecology of Timor birds. In Monk, K. A., de Fretes, Y. \& Lilley, G., eds. The Ecology of Nusa Tenggara and Maluku. Singapore: Periplus Editions: 353-362.

Prawiradilaga, D.M., Baveja, P., Suparno, Ashari, H., Nathaniel, S.R.N., Gwee, C.Y., Verbelen, P. \& Rheindt, F.E. 2017. A colourful new species of Myzomela Honeyeater from Rote Island in Eastern Indonesia. Treubia, 44: 77-100.

Rensch, B. 1929. Beitrag zur Kenntnis der Vogelwelt der Inseln Alor und Lomblen. Journal für Ornithologie, 77: 197-207.

Ripley, S.D. \& Rabor, D.S. 1961. The avifauna of Mount Katanglad. Postilla, 50: 1-20.

Setiawan I., Jati, A., Lesmana, D., Trainor, C. \& Agista, D. 2000. Preliminary analysis of the status and distribution of small Yellow-crested Cockatoos (Cacatua sulphurea parvula) on Alor Island, Pantar, West Timor, Flores and Moyo (in Indonesia). PKA/BirdLife/WWF, Bogor, Report No. 12.

Stattersfield, A.J., Crosby, M.J., Long, A.J. \& Wege, D.C. 1998. Endemic bird areas of the world: priorities for biodiversity conservation. Birdlife Conservation Series No. 7. Cambridge: BirdLife International. 
Simpson, G.G. 1977. Too many lines: the limits of the Oriental and Australian Zoogeographic Regions. Proceedings of the American Philosophical Society, 121 (2): 107-120.

Trainor, C.R. 2005a. Birds of Tapuafu Peninsula, Roti Island, Lesser Sundas, Indonesia. Forktail, 21: $121-131$.

Trainor, C.R. 2005b. Waterbirds and coastal seabirds of Timor-Leste (East Timor): status and distribution from surveys in August 2002-December 2004. Forktail, 21: 61-78.

Trainor, C.R. 2005c. Species richness, habitat use and conservation of birds of Alor Island, Lesser Sundas, Indonesia. Emu, 105: 127-135.

Trainor, C.R., Coates, B.J. \& Bishop, K.D. 2007. Aves de Timor-Leste. Burung-burung di TimorLeste. The birds of Timor-Leste. BirdLife International and Dove Publications.

Trainor, C.R. 2011. The waterbirds and coastal seabirds of Timor-Leste: new site records clarifying residence status, distribution and taxonomy. Forktail, 27: 63-72.

Trainor, C.R., Verbelen, P. \& Johnstone, R.E. 2012. The avifauna of Alor and Pantar, Lesser Sundas, Indonesia. Forktail, 28: 77-92.

Verheijen, J.A.J. 1976. Some data on the avifauna of the island of Roti, Lesser Sunda Islands. Zoologische Mededelingen, 50: 1-21.

Voris, H.K. 2000. Maps of pleistocene sea levels in Southeast Asia: shorelines, river systems and time durations. Journal of Biogeography, 27: 1153-1167.

White, C.M.N. \& Bruce, M.D. 1986. The birds of Wallacea (Sulawesi, the Moluccas \& Lesser Sunda Islands, Indonesia): An annotated check-list. BOU check list No. 7. London: British Ornithologists' Union. 